\title{
Tissue Engineering in Dermatology
}

Merriam-Webster's online dictionary defines tissue as 'an aggregate of cells usually of a particular kind together with their intercellular substance that form one of the structural materials of a plant or an animal' and engineering as 'the design and manufacture of complex products'. These definitions cannot only be applied to biological systems but also to modeling in complex contexts in general.

This special issue of Skin Pharmacology and Physiology is a comprehensive overview on the emerging field of tissue engineering in dermatology. It is intended to provide general information on different cell types relevant in in vitro systems in dermatology, such as melanocytes and skin substitutes. We are aware that such a project cannot cover the entire field of tissue engineering in the skin (at the time of this preface, a Medline search yielded more than 1,600 hits for 'tissue, engineering, skin'). Thus we focused on aspects that are promising in a direction where therapeutical applications are already clinically established (such as wound healing and burns) or are rapidly evolving (such as stem cells). This special issue represents state of the art techniques and knowledge.

On the background of the EU cosmetics directive 76/768/EEC with all relevant amendments, a need for substitution of animal use in testing was implemented. In vitro models play an important part in safety and screening scenarios. Furthermore, the Registration, Evaluation, Authorisation and Restriction of Chemical substances (REACH) initiative of the EU (EC 1907/2006) is intended to improve the protection of human health and the environment through the better and earlier identification of the intrinsic properties of chemical substances'. Here again, complex in vitro models are required with different types of cell systems to test chemical substances and to accurately predict their potential toxic and immunologic hazard to humans and the environment.

We expect the area of tissue engineering in dermatology, namely in the area of product safety for chemicals, cosmetic ingredients and with curative intentions, to grow rapidly in the next decade. The understanding of tissue pathways allows now to specifically design in vitro models for specific testing conditions or even for therapeutically applied tissues, for example in burned patients and chronic wounds.

Some of the presented approaches are highly controversially discussed (such as stem cell research), but will lead to new therapies if not cures of so far untreatable diseases. We are glad to present this supplement from highly profiled authors and their research groups. We are aware that this supplement only represents a part of the current picture of tissue engineering in dermatology. The knowledge is rapidly evolving and will have a broader implementation in general dermatology in the near future.

We would like to thank all authors and the research groups behind for their effort to contribute to this special issue. Such a project would not have been possible without the outstanding support of the staff of S. Karger AG, Basel, namely Ms. G. Hinderling, Ms. S. Ludwig and Ms. S. Braun. We hope that the readership will find the lecture of the thematic supplement informative and stimulating for critical reading.

Joachim W. Fluhr, Berlin Peter Elsner, Jena

\begin{tabular}{ll}
\hline KARGER & (c) 2009 S. Karger AG, Basel \\
$1660-5527 / 09 / 0222-0054 \$ 26.00 / 0$ \\
Fax +41 61 306 1234 \\
$\begin{array}{l}\text { E-Mail karger@karger.ch } \\
\text { www.karger.com }\end{array}$ & $\begin{array}{l}\text { Accessible online at: } \\
\text { www.karger.com/spp }\end{array}$
\end{tabular}

